\title{
Skill and work experience in the European knowledge economy.
}

\section{Introduction.}

One of most common interpretations of the global economic and technological changes which have been taking place since the mid 1980s is that they herald the emergence of a 'knowledge economy' and a growth in 'knowledge work' and high skill employment (OECD 1996; ILO 1998). Moreover, a parallel assumption has been that a 'knowledge economy' is dependent upon education and training and, that there is a positive link between investment in education and training, economic growth and employability (Green et al 1999; OECD 1998). By and large, this assumption covers all areas of economic competitiveness, e.g., individual, the locality/region, firm, sector and nation state.

EU policy has, for some time, stressed the need for closer links to be established between education and the world of work to enable students to broaden the basis of their skill development and, hence, their future employability (Green et al 1997). Amongst other matters, policy makers have affirmed the important role of education business partnership activity as a strategy for fostering such links. Attention has focused in particular upon the role of work experience in general education and vocational education and training (VET), work experience being an example of one type of education-business partnership activity that is undertaken throughout Europe (Griffiths et al 2001). Work experience has been perceived by policymakers as providing an opportunity for students to achieve two objectives: to develop their economic and industrial understanding and, to support their future employability by developing generic skills (i.e. key skills, transferable skills) that are needed to work in the 'knowledge economy'. 
The aim of this paper is to analyse the assumption that work experience can make a valuable contribution to developing students' generic skills and hence supporting their employability. The paper begins by providing an overview and interpretation of the global economic and technological developments, which are assumed to have resulted in the emergence a knowledge economy in Europe, before analysing several features of the role of knowledge within the European economy. The paper then argues that one of the reasons why it has been difficult to discern the implications of the knowledge economy for education and training in general, and specifically for work experience, is that writers have defined knowledge in very different ways. It points out that, depending upon whether knowledge is defined in accordance with traditional scientific or more pluralistic criteria (Spender 1998) it results in quite different conceptions of the knowledge economy. In the case of the former, the concept tends to refer only to those sectors of the economy that are explicitly based on advanced applications of scientific and technological knowledge. In the case of the latter, the concept tends to refer to all sectors where people are actively involved in transforming product and service delivery. For this reason, the paper argues that the concept of generic skill, which policymakers have claimed is a requirement for working in the knowledge economy, is a much more complex issue than has generally been acknowledged and, therefore, presents curriculum planners with considerable problems. The paper illustrates the complexity of generic skill in relation to the initial discussion of the knowledge economy by distinguishing between: (i) those conceptions of generic skill which view it as though it were the property of an individual, and those which view it in terms of a relationship between an individual and the context in which they are working and, (ii) the generic skills called for when undertaking work activities of a fairly routine kind compared with those work activities that are preoccupied with novel or unfamiliar issues. The paper introduces the concept of consequential transition (Beach 1999) as the basis of re-thinking the relationship between work experience, its curriculum context and the development of generic skill. It argues that if work experience is to support and develop generic skill, it will have to be part of a 
'curriculum of the future' (Young 1999), which supports young people to develop the 'practice of learning through work experience' (Guile and Griffiths forthcoming). This involves learning how to: (i) relate the codified knowledge acquired in school or college and the everyday knowledge developed through work experience, and (ii) work collaboratively to develop new knowledge and skill.

\section{The emergence of the knowledge economy.}

\section{Background.}

It has been widely acknowledged that a process of structural transformation has been occurring with increasing rapidity in all advanced industrial states during the last 20 years. This process of economic restructuring is usually attributed to the complex interrelationships and inter-dependencies that exist between the following four key factors.

- the quickening pace of global scientific and technological innovation which has resulted in knowledge becoming more important to global economic development than such traditional factors of production as land, capital and labour (Drucker 1993).

- the emergence of a new techno-economic paradigm which has sometimes been referred to as the 'informational mode of development' (Castells 1995; 2001). The main features of this paradigm are: (i) the application of three new principles value-making, relation-making and decision-making - to work organisation, work design and business-to-business interaction; and (ii) the deployment of information and communication technology to monitor and provide feedback on workflow, product and process performance and sales.

- the scale and impact of global multinational activity, which has resulted in the emergence of more customer-focused organisations, less hierarchical divisions of 
labour and new occupational profiles and new skill requirements (Bartlet \& Ghoshal 1993).

- the global process of industrial convergence which is helping to blur the lines that separated traditional industries, for example, telecommunications, from newer ones, such as media and computing, and create new growth opportunities as technologies and markets converge (Coffee 1997).

Taken in combination, these four factors, although they may vary from one Member State to another according to national, and even regional, circumstances, have been responsible for exerting tremendous pressure for industrial, organisational and occupational change. The next section of the paper provides an overview and interpretation of the debate about the increased role of knowledge within the economy.

\section{The new role of knowledge in the economy.}

The initial interest in the relationship between economic and technological change and the increased role of knowledge in the economy originated in the sociological debate in the late 1960 s and early 1970 s about the transition from an industrial to a postindustrial society (Bell 1973, Touraine 1969). More recently, sociologists have argued that post-industrial societies are being superceded by information (Castells 1995) or knowledge (Stehr 1994) societies. The common theme that links these slightly different interpretations about the continuing pace of economic and technological change is that they each tend to stress that scientific knowledge is now central to most aspects of economic production, political regulation and most spheres of social and cultural life (Delanty 2001).

Stehr (1994) provides one of the most concise explanations of the process of economic and technological change. He conceptualises the changing nature of economic activity 
within industrial societies is as a series of shifts from a material to a monetary and ultimately to a symbolic economy (Stehr 1994).

Historically, as Stehr (1994) observes, most commentators from the early writings of Adam Smith and Karl Marx onwards have accepted that industrial economies have primarily been 'material' economies. In other words, economic activity was primarily based on the use of land, tools and labour. Stehr argues, however, that as industrial economies became more mature or advanced they became 'monetary' economies. Thus, they increasingly required access to capital, in addition to land, tools and labour, in order to support further economic growth and increases in productivity. Stehr further argues, however, that in the modern era industrial economies have become 'symbolic' economies, since the new sources of wealth are based upon the creative capacity of individuals and organisations to use scientific (i.e. codified) knowledge innovatively. Stehr argues, therefore, that, with the exception of the most standardised commodities and services, codified knowledge has become increasingly central to the production of goods and services and is now the primary condition for its further expansion as well as for the limits to growth in the economic world. Thus, according to Stehr, we now live in both a knowledge society and a knowledge economy.

The idea that knowledge now represents the primary source of wealth for industrial economies as well as business and corporate success has become a key tenet of the literature in business economics (Boisot 1998), management science (Drucker 1986; 1993), organisational strategy (Hamel and Prahalad 1994), organisational behaviour (Nonaka and Takeuchi 1995). It is now claimed in these literatures that a new economic and organisational imperative has emerged that is placing firms under increased pressure to use their intangible assets (i.e. the knowledge and skills of their workforce) in order to innovate and create value for shareholders and customers (Kim and Mauborgne 1999; Nonaka and Teece 2001). 
Traditionally, innovation has been viewed as an exogenous process driven by the application of highly abstract and codified forms of scientific knowledge that have been developed outside the workplace (Lundvall 1992). According to writers, such as Boisot, Drucker, Hamel and Prahalad, and Nonaka and Takeuchi, this is a gross simplification. They argue that innovation must also be viewed as an exogenous and an endogenous process. In other words, innovation can be spurred through the exploitation of knowledge or information that is available inside firms and that enables them to offer superior value in their traditional businesses and markets (Kim and Mauborgne 1999). The challenge in the knowledge economy, therefore, is to build, combine and integrate the knowledge assets held by individuals and 'communities of practice' (Nonaka and Teece 2001).

One of the problems that is associated with the above debate about knowledge and knowledge work, as Blackler (1995) has observed, is that most contributors to this debate tend to define knowledge in very different ways and draw different conclusions about which sections of the workforce will become knowledge workers. The diversity of interpretations of the role it is purported that knowledge plays in the economy can be illustrated by employing Blackler's distinctions in relation to four - embrained, encultured, embedded and encoded - different types of knowledge.

Some writers tend to view knowledge as though it was an embrained phenomenon. In other words, it either exists in the form of a mental entity which is located in people's minds or as data which is located in websites. From this perspective, it is suggested that innovation will take one of two forms. It will either involve senior management filling any organisational 'information spaces' by scanning the environment and identifying new sites of information that may provide an organisation with competitive advantage (Boisot 1998), or using managers existing conceptual skills and cognitive abilities to transfer knowledge from one part of an organisation to another (Drucker 1993). 
Other writers, tend to treat knowledge as though it were an embedded entity and assume it is located in social, cultural, technological and organisational contexts. Hamel and Prahalad (1994), for example, suggest that in order for companies to innovate they will have to identify, and subsequently exploit, their 'core capabilities'. They thus imply that the key strategic challenge for companies is to identify the specific combinations of specialist social, cultural and technological knowledge and skill, which provide them with their unique competitive edge in the marketplace, and which will provide a platform for further innovation in the design and delivery of products and services.

In contrast, other writers argue that innovation, and hence wealth creation, is dependent upon the successful acquisition and exploitation of the tacit knowledge (Nonaka and Takeuchi (1995) and Nonaka and Konno (1998); Spender 1996; Wenger 1998). Writers who adopt this position therefore, tend to view knowledge as though it was an encultured phenomenon. Thus, they suggest that if innovation is to become an ongoing concern for organisations, the 'tacit' knowledge that is 'situated' within workplace 'communities of practice' must be made explicit and used to improve product and service delivery.

Finally, other writers have recognised that a considerable amount of knowledge is now encoded in the design of products and services (Lash and Urry 1994) or in computermediated signs and symbols (Zuboff 1988). One consequence of this development is that the scope for further innovations is dependent upon those staff who are either involved in the encoding process or who have access to encoded computer-mediated information having the following skills. They have to be able to mediate between different types of expertise in order to create new products and services (Engestrom et al 1995, Nonaka and Teece 2001) or to develop collective interpretations of symbolic data in order to broker new solutions to organisational problems (Weick 1985). 
The surge of interest in viewing innovation as a knowledge-driven endogenous process indicates that some firms have gradually begun to recognise that the knowledge held or developed endogenously within organisational settings may provide them with a synergistic advantage that is not replicable in the marketplace (Spender and Grant 1996). On the one hand, it has a commercial relevance different to the acquisition of new scientific knowledge, since it can be used to help firms to redefine the competitive problem they face and help them to reconfigure product and service delivery. On the other hand, it introduces a new dimension of skill into work roles that is different from traditional conceptions of skilled performance. In comparison with 'old work roles' where the primary challenge was to coordinate the physical items produced by different employees, the new challenge is to ensure that knowledge about products and services is shared and does not 'stick' to people or within contexts (Seely Brown and Duguid 2001).

Knowledge, however, is not a commodity that can be controlled, moved about or distributed at will. If firms are to innovate by exploiting their 'knowledge assets', they they have to nurture a more reflexive relationship between the knowledge held by customers as well as their own employees (Nonaka and Teece 2001). This has led those firms who wish to compete in the knowledge economy to develop a diverse range of new business development and management strategies to avoid stagnation and accumulate an apply new knowledge to products and markets faster than competitors (von Krogh and Cusamano 2001). Firms have begun to co-opt customer capabilities (Prahalad and Ramaswamy) in order to co-produce new products and services with other organisations (Victor and Boynton 1998). They have support intrafirm transfers of knowledge either by identifying existing features of work environments (Szulanski 1996) or by creating new 'environmental spaces' (Nonaka and Konno 1998) that facilitate knowledge sharing and knowledge production. Third, fimrs have created 
'networks of practice' (Seely Brown and Duguid, forthcoming) to ensure that all parts of an organisation are actively involved in sharing knowledge.

\section{The demand for knowledge work in the European economy.}

A number of significant developments have occurred over the last decade that have been interpreted as confirming the shift towards a knowledge work in the EU economy. The first development is that the process of industrial convergence has been widely proclaimed as constituting evidence of the emergence of 'knowledge-based' production (Olivier et al 1999; Thurow 1999). Two different types of convergence have been distinguished: 'demand-driven' and 'supply-driven' convergence. The former occurs where customers have started to consider products offered by one industry as interchangeable, for example, the competition between EU banking and insurance industry for market dominance in providing financial services. The latter occurs when products from different industries are perceived to work better together than separately. For example, the breaking down of boundaries in ownership, and in product and services development, in the telecommunications, computing and entertainment industries. It has been argued that those industries at the heart of the process of convergence constitute the 'growth industries' of the 21 st century (Thurow 1999) and, as a corollary, the industries where the demand for knowledge work will be most evident (Coffee 1995). According to this view, therefore, knowledge work is specifically a feature of employment in industries whose future development rests on the continued application of scientific research.

The second development is that the significant decline in employment in the primary and manufacturing (i.e. 'blue collar') sectors and a corresponding rise in employment 
in the service (i.e. 'white collar') sector throughout the EU since the late 1980s has also been viewed as evidence of the increased demand for 'high-skill' (Green et al 1999) or or 'knowledge' work (OECD 1995). The continuing trend away from primary industries and towards service industries has been confirmed by the EU's report Employment in Europe (EU 1998). It identified that the five largest growth sectors in the period 1994-1997 were business services, health care, education, recreational activities and hotels and restaurants (EU 1998), accounted for more than 70 per cent of employment growth. In contrast, the five sectors where the greatest job losses occurred were agriculture, textiles, the wood industry, iron and steel and retailing. These sectors accounted for just over half of all the job losses and once again there was considerable variation between individual Member States. For example, Portugual and Greece had the lowest share of this growth, while the highest growth was recorded in Denmark, the Netherlands and Sweden.

Furthermore, a spate of socio-economic structural forecasts, based on expectations about employment trends in the following countries the Netherlands (ROA 1995), the United Kingdom (Wilson and Webb 1995), Germany (Tessaring 1994) and Ireland (Canny and Hughes 1995), have also argued that there will be a continuing trend towards the service sector and 'higher level occupations' in these and other EU countries. The reports concluded that although most of the new 'white collar' jobs in the service sector would be in the professional, technical, administrative and managerial occupations, there will also be an increase in low-skill 'white collar' work, such as personal service occupations, (Robinson 1997; Nickel \& Bell 1995) and a continuing reduction in overall number of people employed in the manufacturing industry (Watkins 1998). The forecasts also noted that although the introduction of new technology in workplaces had resulted in the rise in the demand for 'white-collar' work, not all sectors were necessarily generating new jobs (ILO 1998), nor looking for 
higher levels of skill (Freeman 1997). The conception of knowledge work that surfaces here echoes Machlup's (1962) original definition: forms of work which were responsible for producing and transmitting information that helped people to learn something they had not known previously.

The third development is the re-appraisal of the relationship between organisational structures, systems and processes to organisational performance, which has been interpreted as confirming a growing demand for 'high-skill' (Green et al 1999; Tessaring 1997) or 'knowledge' (OECD 1996) work throughout Europe. Apart from resulting in the decentralisation of authority for business decisions to front-line units, the de-layering of organisational management hierarchies, the out-sourcing of nonessential services, this process of re-structuring has also gradually broadened work roles, occupational profiles and conceptions of skill and expertise in many industrial sectors (Mason 2000) and organisations throughout Europe (Guile and Fonda 1998). One manifestation of these developments has been that organisations are placing a higher value on skills, such as 'horizontal communication' (Green 1999) and ' ' (Brennan et al 2001) in an attempt to assist them to respond more swiftly to customers' needs or even co-produce products and services with customers. This development suggests that some organisations are beginning to define knowledge work in terms of the types of behaviour that support knowledge sharing and knowledge creation to enhance product and service delivery as much as in terms of the level of qualifications held by employees.

\section{The extent of the shift towards knowledge work in the EU economy.}

One of the reasons why it is difficult to ascertain the extent of the shift towards 'knowledge work' in European economies is because writers tend to adopt different starting points in terms of how they analyse firms' responses to the intensifying impact of globalisation and interpret the empirical evidence about industrial and occupational change. 
An early attempt to pin down the range of firms' responses to globalisation was provided by Bengtsson (1993). He identified that firms could respond in three main ways in which firms to increased competitive pressure. He did not, however, assume that these ways constituted a stage of development that every firm would inevitably pass through. Bengtsson argued that firms could improve their competitive position by: (i) slanting their skill formation strategies to support the development of their existing range of products and services (i.e. the 'product-driven' stage); chosing to build up a reserve of skill to assist them to move into new markets through making education and training a permanent feature of their business development strategy (i.e. the 'marketdriven' stage) or (iii) placing a much stronger emphasis upon utilising knowledge and information in novel ways to either solve organisational problems or to innovate and create new products ('knowledge-intensive' stage). Bengtson acknowledged, however, that the third phase tended to emerge only in those firms, or parts of firms that were seeking to become 'knowledge-intensive' organisations, since this development significantly altered product and service strategies and skill formation strategies.

An alternative explanation of firms' responses has been provided by Schumann (1998). He argued that European firms have adopted one of two main models of production. One model is based on an intensification of Tayloristic principles of work organisation. This may be exemplified by the idea of 'lean production', as presented by Womack et al (1999). According to their analysis, although lean production involves providing worker with more freedom to control their work, it only provides limited opportunities for using the 'work process' knowledge (Boreham 1999), which is held by organisational 'communities of practice', to solve workplace problems. The other model, which Schumann refers to as the 'structurally innovative model' involved organisations extending responsibility and a high degree of discretion for selforganisation of technical and management functions and encouraging workers to use 
their collective knowledge of work processes to develop novel solutions to organisational problems.

In contrast, Regini (1995) has highlighted how competitive pressure has led companies to link their product and service strategy closely to their skill formation strategies in different ways. Regini identifies the existence of two radically different models of skill production in the EU. One model, the 'high added value' model, tries to support product and service innovation and increase productivity by generating a flow of skilled labour inside companies in excess, both quantitatively and qualitatively, of actual company demand. The other model, the 'low added-value' model, gears the supply of skill to meet demand for existing products and services. In other words, firms' concentrate upon those segments of the labour market deemed crucial at a particular time and targeted those for training and development.

Interpeting the empirical evidence as to whether the shift from 'blue' to 'white' collar actually constitutes evidence of an increased demand for knowledge work is also notoriously tricky. It appears that not all new occupations actually generate additional 'high skill' / 'knowledge' work nor do they necessarily require higher levels of knowledge and skill (Tessaring 1997). Sometimes new occupations have in reality been little more that the substitution of one form of employment for another. For example, in the field of media and communication technology, traditional occupations such as graphic artists, designers, media technicians etc, have been replaced by new media occupations such as media operator, media designer. In other cases, although genuinely new occupations have emerged in, such production areas as sports and leisure, designer clothing, furniture, there is very mixed evidence about the 'knowledge' component of the work (Tessaring 1997).

Furthermore, the introduction of broader occupational profiles does not necessarily indicate a shift towards knowledge work. Some occupational profiles have simply been 
're-classified' as a result of a range of fairly undemanding technical or commercial tasks being introduced into existing administrative or clerical job (Tessaring 1997). For example, the introduction of ICT in the banking industry means that the work of administrative or clerical staff has been re-classified as technical/commercial, since staff now devote a greater amount of time to monitoring financial transactions compared with the past. In contrast, other occupational profiles have been 'expanded' as a result of an enlargement or enrichment of work roles due to the drive to encourage employees to assume greater responsibility for adding value through self-management of work processes, work relationships and customer relationships (Guile and Fonda 1999). For example, changes within the medical profession have resulted in doctors and nurses assuming responsibility as process managers for health services and facilities. These developments have not necessarily increased the level of medical knowledge and skill which doctors and nurses require, however, they have significantly broadened the contexts in which they are expected to work, the range of expertise they are expected to mediate between, the roles they are expected to perform and the accountability associated with work roles. In this sense, the range of and type of knowledge and skill required by professionals, such as doctors and nurses, has been radically enlarged.

The links between product and service quality, competitive advantage and knowledge work, therefore, are not as simple and unidirectional as many policymakers and some researchers claim (Keep 1999). This is partly because, depending upon market segment and product development strategies, firms can still chose to adopt either 'high' or 'low' added-value models of production and skill formation and remain economically viable for the foreseeable future (Bengtson 1993; Regini 1995). The choice between models of production and skill formation would suggest that the demand for 'science-based' knowledge work in the EU, as well as elsewhere in the world (Florida 1995), is most likely to surface either in specific regions (Cooke and Morgan 1998) and sectors which constitute the 'growth industries of the future' (Thurow 1999). 
It is also partly because many researchers in organizational science and business economics have attempted to explain how firms addressed their competitive problems by focusing on how they deployed science and technology as 'solutions' to their perceived problems, rather than analysing how exogenous strategies can support product and service development (Kim and Mauborgne 1999). Increasingly, more and more firms are focusing on 'knowledge-based' innovation (Kim and Mauborgne 1999). In other words, they are redefining their competitive problems by identifying their core competences and their internal knowledge creating strategies and focusing on the performance criteria that matter to customers and adopting business and management strategies that reflect customers' value preferences (Prahalad and Ramaswamy 2000; von Krogh and Cusamano 2001). One consequence of the emerging interest in becoming a 'knowledge creating company' (Nonaka and Takeuchi 1995) has been that a much more pluralistic concept of knowledge has been introduced into the debate about the knowledge economy and knowledge work (Spender 1998).

If the concept of the knowledge economy and knowledge work are to be defined solely in terms of the secondary elaboration of science, the transition to this type of economy and work throughout the EU is likely to be a slow and uncertain process. Furthermore, it is likely that, even in those regions and sectors that are characterised by sciencebased production, 'low-skill' work will continue to flourish (Finegold 1999). In contrast, if a more pluralistic interpretation of the concept of the knowledge is adopted that reflects the range of ways that firms can act to improve their product and service strategy, it is far less easy to determine the extent of the transition to a knowledge economy. For example, recent evidence estimates that only about a quarter of all enterprises in Europe have adopted 'knowledge-based' product and service strategies (OECD 1996). Nevertheless part of the reason for this slow transition to 'knowledgebased' organisations is that firms are either reluctant to engage in wholesale organisational change or slow to grasp the full implications of the strategic decisions 
that they have taken (Oesterman (1994). Firms fail to recognise that they have to fundamentally re-think the relationship between business strategy, organisational design, human resource management and human resource development if they are to successfully compete on the basis of knowledge and capability (Guile and Fonda 1998).

Policymakers have rarely addressed the complexity of the issues surrounding the debate about the knowledge economy and knowledge work in the EU. In fact, the concept of the knowledge economy has primarily been treated as a new reality or context that people must adjust to. This assumption has resulted in a widespread demand from policymakers throughout Europe for national education and training systems to support young people to develop the forms of generic skill, which they have commonly assumed are an essential requirement for working in a knowledge economy. This is a highly laudable goal: it introduces a future-oriented perspective to EU education and training policies. Unfortunately, policymakers have failed to appreciate a number of issues, the first of which being that the concept of generic skill is a much more complex issue than has been recognised. The second issue is that the type of knowledge required in a knowledge economy, as the preceeding debate has indicated, is much more multi-faceted than the concept of knowledge associated with many definitions of generic skill. The third issue is that developing generic skill in academic and vocational curricula poses problems that have, so far, not been explicitly addressed. These issues are explored in the next sections of the paper.

\section{The concept of generic skill and the knowledge economy.}




\section{Introduction.}

The concept of skill has been ubiquitous in industrial sociology, human resource management and development and vocational educational and training. Yet, as Attewell (1990) has noted, different theoretical traditions are often blind to their own preconceptions as regards the complexities and ambiguities of their definitions of skill. This can be seen clearly as regards the eclectic way that the concept of skill has been defined and used. Traditionally, it has served two purposes (Darrah 1994). The concept of skill has provided the basis for an analysis of both the characteristics of jobs (e.g. task demands and role requirements) and the qualities of people who perform them (e.g. abilities, talents and capabilities). As a result, the social scientific and educational studies literature has shared certain common assumptions about the relationship between work and individuals.

\section{The traditional view of skill.}

One of the main assumptions that underpinned traditional or occupationally-specific conception of skill was that jobs were fairly stable, that they could be broken down into constituent parts, and that the resulting bundles of characteristic 'skills' were essential for the performance of certain forms of work. Another assumption was that the 'skills' that have been identified are required and that in some direct, obvious way, if they were absent, the work would not get done. Thus, as Darrah (1994) points out, there is a particular individualism implicit in the traditional concept of skill requirements. It presumes that workers not only possess the requisite skills, but also that individual jobs have to be performed by skilled incumbents if they are to be accomplished successfully. Furthermore, it was also assumed that people could be separated from the contexts in which they work. Consequently, models of skill and/or competence development that emanate from radically different traditions such as, cognitive psychology (Dreyfuss \& Dreyfuss) and vocational education and training (Jessup 1991), have been inclined to treat the workplace as a backdrop to the actions of 
individuals. It has simply been viewed as a constraint upon the human actions that are performed within it.

The legacy of these ideas about the relationship between skill and work can be traced in the design of most vocational curriculum programmes and vocational qualifications and, moreover, in the use of work experience as a component of those programmes. Irrespective as to whether vocational programmes were delivered in the workplace or a training institute, they have tended to replicate the idea that skill can be broken down into constituent elements by designing discreet curriculum units to teach or train people to acquire these specific 'skills'. This approach to the design of vocational programmes and qualifications, as Tuomi-Gronin \& Engestrom (forthcoming) have observed, rests on Thorndike's (1924) notion of 'identical elements' (i.e. matching elements of skill to elements of training programmes). One consequence of the enduring influence of the notion of 'identical elements' has been that training programmes tried develop 'skills' in workers by providing tasks that would improve the operation of their mental faculties, such as memory or attention, or their physical performance such as, manual dexterity and spatial awareness. Another consequence has been that most vocational qualifications reinforced these very task specific notions of occupational skill by accrediting individual elements of skill separately from one another (Tuomi-Gronin \& Engestrom forthcoming).

The above assumptions about the relationship between work tasks, the elements of skill and the design of training programmes have been assimilated over a period of time into the language of many EU policymakers. Thus, as Keep \& Mayhew observe (1999), even when policy makers talk about the need for more generic forms of skill, they still tend to refer to skill in accordance with very traditional criteria. They present it as though it were a characteristic of a well-defined work role and a clear specification of desired qualities. Moreover, policymakers retain a belief that qualifications can be used to certify accurately the level of skill attainment. Defining, 
developing and assessing generic skills, however, raises more complex questions than have so far surfaced in the EU policy debates.

\section{The concept of generic skill.}

It is widely accepted that the organisational and occupational changes that were described earlier have resulted in an increased demand from employers for broaderbased forms of skill (Green et al 1998; Kämäräinen \& Streumer 1998; Nijhhof and Streumer 1998). The concept of generic skill, however, has to be treated with great care for a number of reasons.

Most generic concepts of skill mention 'teamwork', 'flexibility' or 'problem-solving' as a necessary skill. Qualities, such as teamwork', however, are not a skill but a description of how work is or is not organised. What constitutes a 'team' is subject to local definition and thus must be defined in relation to the working context (Darrah (1994). The idea of teamwork also presupposes a clear sense of purpose about the activities teams are expected to undertake and an indication as to the type of knowledge, performance and result teams are expected to achieve. This implies that the above qualities are not solely attributes of individuals, they are developed through participation in 'communities of practice' (Lave and Wenger 1991) and hence are shaped by the actual context of work (Boreham 1999).

When thinking about generic skill, therefore, it is important to differentiate between the type of knowledge and skill that are required for routine activities as opposed to more novel forms of work activity. This relationship between types of work and types of generic skill alerts us to the extent to which young people might have to call upon any of the following types of generic skill. They might have to: (i) resituate their existing knowledge or skill in a new context to help solve a routine problem or 'unforeseen event' or 'problematic situation' (Boreham 1999; Fischer 1999); (ii) participate in a workplace 'community of practice' in order to gain access to the human 
and technological resources that reside in such 'communities' in order to solve routine or unforeseen problems (Wenger 1999); and (iii) work collaboratively with others to address novel problems (Eraut 1999).

Problem solving is another activity that has been commonly defined as an important generic skill. Problem solving, however, is closely associated with the issue of problem identification and these issues are handled very differently in different work contexts (Stasz 1998). As Stasz has argued, in some occupations, for example health care, problems are identified as a result of 'situational assessment' in other words identified and solved by the work team and this may involve technical adjustments as well as changes in occupational roles. In contrast, in other occupations, for example the construction industry, senior staff tend to assume responsibility for identifying problems and the workforce are only called upon to contribute to 'solving' certain aspects of the overall problem.

The concept of generic skill, therefore, is characterised by its own complexities and ambiguities which are not always fully made explicit. This situation is further compounded through the influence the different perspectives that inform and underpin the debates and discourses about generic skill within EU education and training policy and in academic research in vocational education and training. The following discussion highlights four different conceptions of generic skill that have surfaced in the social scientific and educational studies literature. In doing so, it draws on the insights about the relationship between skill and work context that have been highlighted by Darrah and others.

\section{Different types of generic skill.}

One of the most common uses of the concept of generic skill is to describe the extent of a young persons' 'work readiness' (Keep and Mayhew 1999). In some cases this amounts to little more than a demand for basic motivational skills and habits, such as 
honesty, punctuality, following instructions. In other cases, it reflects a demand for, what Nickson et al (1999) have referred to as, the 'aesthetic-skills' that are associated with routine employment in certain sections of the service industry. This might include the ability of employees either to manage their feelings and appearance in order to serve the perceived interests of customers (Taylor 1998), or be endowed with certain types of accent that reflect specific socially and culturally defined conceptions of performance and acceptability and to exhibit certain styles of appearance, for example, hair style, clothing and physical size (Nickson et al 1999).

A second use of the concept is to employ it to refer to the qualities which it is assumed are required in modern workplaces. One of the problems associated with this approach to generic skill is that different national education and training and social partnership traditions mean that differences in terminology about generic skills refer to real differences between underlying approaches to skill development and assessment (Kamarainen and Streumer 1998). This issue can be illustrated by examining the different conceptions of generic skill that are associated with education and training policy in the UK, Germany and the Netherlands.

The term, 'key skill', is employed in the UK to describe the generic skills which are assumed to be relevant to most forms of modern work and which can be developed in education. One group covers communication, application of number, application of ICT and another covers such things as improving own learning, problem-solving, etc.) UK educational policy assumes that 'key skills' are important for future learning and hence for mobility in the labour market (Payne 2000). Furthermore it implies that skill can be defined in a highly individualistic way that does not take account of the influence of context on development and performance (Guile and Fonda 1999). 
In contrast, the use of the term 'key qualification' in Germany and in the Netherlands refers to a much more holistic notion of skill. It explicitly embraces the relationship between the formal component of education (i.e. school/college) and the context (i.e. workplace) in which skills are acquired (Onstenk forthcoming). The idea of 'key qualifications' traditionally denoted the abilities that transcended traditional divisions of labour and traditional occupational profiles (Simoliet et al 1991), for example, the personal competences needed either to 'unlock' the potential to memorise and retrieve information or to understand work processes and work relationships. They now also take explicit account of the need to integrate specialist knowledge, social and participative competences and opportunities to master new production concepts and contribute to the development of organisational learning cultures (Kämäräinen \& Streumer 1998). Thus, a central tenet of German and Netherlands policy is that competence / skill development presupposes that young people have opportunities to explore the relationship between 'codified' and 'everyday' knowledge. In this sense, the idea of 'key qualifications' implies a more contextual and less individualistic conception of skill.

The concept of generic skill has been used in industrial sociology and political economy to refer to the specific capabilities which are required for professional and technical work. Flecker \& Hofbauer (1998), for example, employ the term 'intrapreneurial' skills to describe the ability of skilled workers to combine 'technical' skills (i.e. knowledge of products and operational systems), 'functional skills' (i.e. managing personal performance) and 'motivational skills' (i.e. commitment to organisational goals) in order to ensure to continuous improvement in modern production systems. In contrast, Reich (1991) has identified the type of generic skills required by graduates who are seeking employment in the knowledge economy. He employs the term the 'symbolic analyst' to describe the capability to solve problems, take risks, broker solutions and maintain a systems perspective on work roles. Although Flecker and Hofbauer and Reich are describing the skills required for 
different types of work, they tend to define skill as though it were the property of an individual. Thus, they play-down the influence of the context of work and the division of labour upon the development of skill and, moreover, imply that once individuals have developed, for example 'problem-solving' capabilities, they will be able to freely deploy such abilities in any context.

Rather different conceptions of generic skill have emerged in the organizational studies and in socio-cultural activity theory. These conceptions are less individualistic and try to take greater account of the influence of the context of work upon skill development.

The term intellective skill (Zuboff 1988) has been coined to refer to type of skill required to respond to the challenge of working in environments that provide access to encoded knowledge (i.e. symbolic data) compared with working in environments that do not provide access to such data. Zuboff argues that one of the defining characteristics of intellective skill is working collaboratively with others to interpret 'embedded' or 'situated' knowledge and to use it to broker solutions to problems that arise within workplaces.

In contrast, the type of skill required for working in flat, team and network-based organisations has been defined to as polycontextual skill (Engestrom et al 1995). (Engestrom et al employ this term to refer to the increasing demand on members of work teams to engage simultaneously in multiple activities, enter 'territory' with which they are unfamiliar and, in the process, call upon and utilise different forms of expertise to resolve workplace dilemmas. Furthermore, Engestrom et al, in common with other researches (Guile and Young forthcoming), argue that polycontextual skill presupposes that people have the capability to cross 'organisational boundaries' in order to collaborate with other 'communities of practice' in order to mediate between different forms of knowledge. Engestrom et al note that this 'boundary crossing' appears to be as much a feature of new product development and technological 
innovation as it is more traditional forms of work, such as teacher education, community and social work and industrial production. In contrast to the other conceptions of generic skill discussed, Zuboff and Engestrom et al recognise that, in order to innovate and solve problems, people have to be able to mediate between different types of knowledge held by experts and between different work contexts and social relationships. In this sense, they are much more conscious of the social, cultural and communicative basis of skill compared with many other writers.

\section{Generic skill and the 'knowledge economy'.}

One way of making sense of the contrasting foci and emphases that are associated with the concept of generic skill is to distinguish between those conceptions which view it primarily as though it were the property of an individual and those conceptions that explicitly recognise the contextual basis of skill. This distinction helps to distinguish between first, the diverse range of meanings associated with the term in the policy and academic literature that were discussed in the previous section. Second, the diverse demand for generic skill, since it is clear that the concept serves as an all-inclusive, umbrella term to encapsulate the skills required in different work contexts. These issues also alert us, therefore, to the complex nature of the problems that policy-makers face as they try to devise educational policies and reform qualifications in order to support young people's employability in the EU knowledge economy.

[Insert Table 1: A typology of generic skill]

Traditionally, the main role of qualifications has been standard-setting, thus denoting the proportion of any population that had achieved a specific level of academic or vocational attainment. The emphasis on generic skill, however, represents a shift towards demonstrating a potential to achieve in future, albeit in different ways from those normally associated with conventional qualifications. As Chisholm has cogently argued (1998), qualifications are both losing relative significance as well as gaining 
absolute significance. By this she means that credential inflation has fuelled expectations amongst employers for higher levels of qualifications, while the emerging demands of the knowledge economy has simultaneously forced employers to look for broader evidence amongst new recruits of the capability to develop the skill of using knowledge effectively in the workplace.

Another way of making sense of the concept of generic skill is to distinguish between those conceptions which presuppose a focus on work activities of a fairly routine kind compared with those work activities that are preoccupied with novel or unfamiliar issues. This distinction presents vocational educators and workplaces with a set of problems that the different contributors to the debate about generic skill rarely acknowledge, since their primary focus is identifying changing conceptions of skill and not skill development. Addressing the problem of how to prepare young people to engage in routine and novel work activity involves two separate, but linked, issues. The first problem is how to assist young people to develop context-free skills in context-specific situations (Young 1999(b)). This is not easy since it is extremely difficult to specify the nature and level of, for example 'intellective' and 'polycontextual' skills and, moreover, the learning potential of workplace varies enormously (Guile and Young forthcoming). The second issue is how to design a curriculum which provide young people with opportunities to relate the 'codified' knowledge they acquire through formal study to the 'everyday' knowledge they acquire in workplaces, in order that they can develop new knowledge and skill (Guile and Griffiths 1999). Re-thinking these challenges, however, is slowly forcing greater attention to fall on the role of work experience in general and vocational education. Partly because work experience provides an opportunity for young people to 'connect' different modes of learning to one another and, in the process, develop new knowledge and new skill. 


\section{Educational policy, work experience and employability.}

\section{The transition from education and training to working life.}

In response to the challenges presented by economic and technological restructuring, EU Member States, in common with other countries, have undertaken a considerable number of initiatives to support the transition of young people from school-to-work and enhance their future employability (Stern and Wagner 1999). Two of the most common measures have been to encourage schools and colleges to increase the opportunities for post-16 students to undertake work-experience and to fund new educational programmes for unemployed or disaffected young people that include a work experience component (Griffiths et al forthcoming). Despite these initiatives, the transition of many young people into employment is still highly problematic.

One explanation for this problem is that since employers are increasingly faced with a surfeit of qualified applicants, they actively look for generic skills that are not solely accounted for by formal credentials (Chisholm 1997). Most EU countries have assumed that one of the most effective ways of helping young people to develop generic skills was to increase their access to work experience (Griffiths et al forthcoming). Unfortunately many models of work experience in general and vocational education have addressed new issues about skill development by relying on old models of learning in the workplace (Guile and Griffiths 2001). Most models of work experience are geared to quite traditional conceptions of work and work roles, based on fairly mechanistic conceptions about the process of learning and, as such, fail to support students to develop more 'future-orientated' capabilities, for example, seeing the limitations of existing forms of work practice and working with others to conceive of alternatives. Despite the best intentions of policymakers, therefore, work experience has often ended-up affirming the idea that its main purpose is to assist young people to learn how to re-produce pre-existing activities. Consequently, very 
little attention has been given as to how to prepare young people to move between different types of work contexts and how to relate formal and informal learning.

\section{Re-thinking work experience as 'consequential transition'.}

One of the most interesting insights into understanding the process of learning that occurs through work experience has been provided by Beach (1999) and Beach and Vyas (forthcoming). Beach's work originates in socio-cultural activity theory and, as such, it is not primarily concerned with addressing the development of generic skill. His ideas about transition, however, help to throw new light on the debates about how work experience can assist students to make effective transitions from education to work (Guile and Griffiths forthcoming).

Beach argues that rather than seeing work experience as a strategy whereby students learn to the transfer of knowledge and skill acquired in one context (work) into another context (education), it is important to see it as a process of consequential transition. The idea of consequential transition is about movement in relation to purposes and, therefore, Beach argues that greater account needs to be taken of how, in the process of transition, identities and even contexts themselves might change.

Beach identifies four different types of consequential transitions - lateral, collateral, encompassing and mediational, although he acknowledges that there are certain affinities between the first and second pair of transitions. Lateral and collateral transitions involve people moving between sets of activities that are changing slowly compared to the changes that individuals are experiencing as they move between them. Beach and Vyas" account of high school students working in a fast food restaurant illustrates this type of transition. Students had to adapt to the restaurant and acquire the ability to produce and deliver hamburgers. In contrast, he suggests that encompassing and mediational changes occur when the rate of change in an activity is relatively rapid compared to the change that is required by the individual involved. He suggests that 
these types of transition occur when new technology is introduced in workplaces and workers often have to develop new skills without being able to seek advice from more experienced staff who, themselves, are still coming to terms with the change.

The concept of consequential transition is relevant to re-thinking how work experience might support students to learn and develop in several senses. First, it can be used to question the conventional notion that moving from school-to-work is relatively unproblematic provided students have the appropriate skills and personal attitudes. Such a view supports the idea that it is a fairly straightforward matter of building 'employability skills' into school/work curricula (Taylor 1998). This approach fails to acknowledge that formal and informal learning serve quite different purposes. The aim of the former is to ensure that students acquire the 'codified' knowledge that is required in order to pass examinations, while the aim of the latter is to supports students to acquire the 'everyday' knowledge that may help them to operate effectively in workplaces. This suggests that far greater thought has to be given as to how to support students to use their formal and informal learning to develop new insights and build new knowledge.

Second, it reminds educators and policymakers that transition is not merely a matter of 'launching' a student to learn in a workplace. Workplaces are very different and learning opportunities are not distributed equally across them. In 'knowledge-poor' workplaces, for example a Fast Food restaurant, learning goes on and is expected, but it is not a high priority, relative to delivery, the primary goal of most activities is to support a highly standardised form of product and service delivery. The knowledge and skill that can be acquired are unlikely to have little value outside of that specific context of work. In contrast, in 'knowledge-rich' workplaces young people are likely to have opportunities to participate in specialist 'communities of practice' and be encouraged to engage in activities that allow them to acquire broader forms of knowledge and skill. This implies that one of the challenges is to design models of 
work experience that provide a foundation for young people to make a transition into work contexts that involve addressing routine as well as novel work problems.

The third issue Beach's work identifies is that work experience constitutes a form of 'horizontal development' (Beach 1999). Traditionally, most studies of human development assume that the process of knowledge and skill acquisition are hierarchical processes that either involve apprehending sets of concepts of ever greater abstraction or involve mastering higher levels of technical or craft-based skill, in other words codified knowledge. Beach argues that learning at work is a 'horizontal' process, by that he means young people acquire 'situated' knowledge rather than codified knowledge. And moreover, this situated knowledge can take a variety of forms. It could be knowledge about how to participate in a 'community of practice', change and vary work practices or hoew to connect diferetn fragments of codified knowledge to resolve work problems. Consequently, Beach argues that if young people are to benefit from work experience, they have to 'learn how to negotiate their own learning' in a new context and in a different way from how they learn in school or college.

Beach's analysis suggests, therefore, that it is not work experience per se that is inspiring and that leads young people to develop the generic skills that enables them to 'learn how to negotiate their own learning', or to use their codified knowledge to analyse workplace problems debate critically different ways of tackling such problems. Rather it is the meaningful and dialogic engagement in a 'community of practice', inspired by a shared motive, that helps students to filter out actions, arguments and solutions and thereby develop their teamwork or problem-solving capabilities. In this sense, his analysis recognises an extra dynamic in the process of learning through work experience, one which must involve the exploration of new territory for which prelearned response and solutions are unavailable. Consequential transitions involve the construction of new knowledge, identities and skills or the transformation (rather than 
the application or use) of something that has been acquired elsewhere. A transition of this form involves a notion of progress and is best understood as a developmental process. Such transitions may involve changes in identity, as well as changes in knowledge and skill, thus, they are processes that involve the full person not just learned attributes or techniques.

The notion of consequential transition and the distinction between the process of 'vertical' and 'horizontal' development have implications for the design of work experience in vocational or general education (Guile and Griffiths 2001). In the past it made sense to associate classroom learning with the acquisition of subject knowledge and workplace learning as something taking place incidentally during activities designed for other purposes. However, as the learning demands first, on educational institutions are beginning to change because of the exhortation from policymakers to create a lifelong learning culture; and second, on workplaces through their desire to become 'knowledge-creating' organisations, the old distinction between different sites of learning is becoming obsolete. Making either of the above forms of 'learning' a priority involves developing new learning relationships between education and work and within education and work. The challenge, therefore, is to recognises the contribution that different forms of learning can make to one another. A central requirement for such a curriculum will be to find a way to support young people to relate their 'vertical' and horizontal' development and to develop new knowledge and skill.

\section{Work experience, employability and a 'curriculum of the future.}

Some promising suggestions for re-thinking the relationship between 'vertical' and horizontal' development have been put forward by Young (1999(a)) and Guile and Young (forthcoming). Young has argued that any attempt to relate different types of knowledge and different processes of learning involves addressing the issue of curriculum specialisation, since it is subject specialisation that lies at the heart of the 
separation of work from education, vertical development from horizontal development etc. He acknowledges that though curricula will necessarily involve hierarchical assumptions about learning goals, they need to be built on a more realistic understanding of how students actually acquire the tacit knowledge involved in participating in 'communities of practice', whether in workplace or in educational institutions. Young introduces the concept of connective specialisation to conceptualise the basis of this new relationship between the priority given to subject knowledge with the learning that occurs outside of formal settings and the knowledge that is acquired through participating in 'communities of practice'.

The idea of connective specialisation provides new principles for thinking about how work experience can support young people to relate their formal and informal learning, develop new knowledge and skill and hence support their employability. Traditionally, work experience has provided access to types of knowledge and modes of learning that are not tied-in to school, college or university subjects, while schools and colleges have provided access to fairly stable and insulated curricula (Young 1998). In order to assist students to connect their formal and informal learning and use these 'connections' to develop new insights, knowledge and skill, work experience has to become part of new programmes of learning that do not rest either on the assumed separation of or superiority of modes of knowledge and learning.

This principle of 'connectivity', therefore, involves viewing the development of knowledge and skill as a process of 're-situation' (Guile and Griffiths (forthcoming). Instead of seeing the acquisition of codified knowledge as a process in which young people are taught to decontextualise their actions and thoughts and the development of skill as a process which is, at best, tenuously related to abstract thought, educators and policymakers, therefore, will have to work together to ensure that new learning goals and new learning processes are introduced to help young people 'progressively recontextualise' their knowledge and skill. 
It is important to distinguish between two types of re-situation. The first involves assisting young people to carry out a known activity in new context. In work experience an example would be when a young person undertakes a task that they have already carried out previously, for example using a computer. The second type of resituation occurs when individuals and groups use the problems that arise while undertaking a task as the basis for developing a new pattern of activity in a new context. An example might be when a student nurse recognises that 'taking a patient's temperature' is not just a task on it own; knowledge of a patient's temperature can help a nurse to diagnose the state of his/her health. With appropriate pedagogic support and access to new knowledge, a nurse can develop her/his knowledge of diagnosis out of the activity of measurement. They argue that this second type of resituation can lead people to develop new goals, new actions and new strategies in order to grasp the connection between different activities.

The process of grasping connections in workplaces, which Guile and Griffiths (forthcoming) have referred to as the 'practice of learning through work experience', may take one of two forms. One form entails new patterns of activity and new meanings emerging from the original context which constitute a modification of the original activity rather than an alternative realisation of that activity. The other form occurs when it is not possible to resolve an original problem unless there is contact with ideas that lie outside of the immediate situation. Acquiring the 'practice of learning through work experience' involves supporting young people to develop a more iterative relationship between 'codified' and 'everyday' knowledge. This can occur in the following ways. First, supporting young people to use the potential of subjects as conceptual tools for linking their workplace experience to their programmes of study as well as using work experiences to transfrom their understanding of the relationship between theory and practice. Second, ensuring learners develop the intellectual basis to criticise existing work practices in school and 
at work and take responsibility for working with others to conceive of alternatives. Third, encouraging learners to resituate their everyday knowledge and skill in new contexts as well as encouraging them to contribute to the development of new knowledge, new social practices and new intellectual debates. Fourth, developing their confidence to cross organisational boundaries or the boundaries between different, and often distributed 'communities of practice'; and connect their knowledge to the knowledge of other specialists whether in educational institutions, workplaces or the wider community.

\section{Conclusion}

This paper has explored the extent to which work experience can help young people to develop generic skill and thus support their employability in the emerging EU knowledge economy. It has set the link between work, work experience and skill in the following three contexts. First, it has explicitly taken account of economic and technological changes which have given rise to the emergence of a knowledge economy in Europe. Second, the paper has argued that the concept of generic skill, which policymakers have claimed is central to working in the knowledge economy and that can be developed through work experience, is more complex than is normally acknowledged. In order to identify the complexity of the concept, the paper has introduced a typology of generic skill. The typology illustrates the difference between those conceptions which view skill as the property of an individual and those which view it in terms of a relationship between individuals and context; and the difference between the difference between the way skill has been conceptualised in relation to fairly routine work activities or to novel work activities. Third, the paper has argued that the increasing demand by employers for more generic skills or competences presents workplaces and vocational educators with an entirely new set of problems. They have to try to help young people to develop context-free skills in context-specific situations and, in order to do so, have to assist them to relate two different modes of 
development to one another. The paper concludes by arguing that the concept of consequential transition and connectivity provides the basis for re-conceptualising how work experience can support students to develop generic skills. These concepts help to focus policymakers' and educationalisits' attention on new curriculum strategies for relating the different types of knowledge (i.e. codified and everyday) which are developed in formal and informal education as well as the different types of learning (i.e. vertical and horizontal development) which occur in these respective contexts. In doing so, the paper has suggested that a fundamental reappraisal is required of the relationship between the assumed links between work experience, generic skill and employability in EU education and training policies for secondary, higher and lifelong education.

This paper is based on research which was undertaken as part of a TSER Fourth Framework Research Project: 'Work Experience as an Innovative Education and Training Strategy for the $21{ }^{\text {st }}$ Century'. The final report was submitted to the EU in February 2001 (Griffiths et al).

The author would particularly like to thank Graham Attwell, Toni Griffiths and two anonomous referees for their helpful comments and suggestions as regards developing this paper. Any mistakes or inaccuracies are attributable to me. 


\section{REFERENCES}

Ashton, D. and Green, F. (1995) Education, Training and the Global Economy, Edward Elgar, London

Attwell, G. (2000a) The role of work experience, work process knowledge and social shaping in the current reshaping of educational strategies in Europe, paper presented at the European Conference on Educational Research, Edinburgh

Attwell, G. and Jennes, A. (1996) Work process knowledge and new forms of development of professionals for Vocational Education and Training, paper at Third Work Process Knowledge Meeting, Bremen, Dec. 12-14

Attewell, P. (1990) What is Skill? Work and Occupations Vol 17. No 1. 423-448

Bartlett, C. Ghoshal, S. (1998) The Individualised Corporation, Harvard Business Press

Bartlett, C. and Ghoshal, S. (1993) 'The Changing Role of Top Management', Harvard Business Review, May/June pp. 90-96

Beach, K. (forthcoming) 'Consequential Transitions: a socio-cultural expedition beyond transfer in education', Journal of the Learning Sciences

Beach, K. and Vyas, S. (1998) Light Pickles and Heavy Mustard: Horizontal development among students negotiating how to learn in a production activity, paper presented at the Fourth Conference of the International Society for Cultural research and Activity Theory, University of Aarhus, Denmark.

Bengtsson, J. (1993) Labour markets of the Future: the challenge to education policy makers, European Journal of Education, Vol 28, No 2. 135-156

Blackler, F. (1995) Knowledge, Knowledge Work and Organisations: an Overview and Interpretation, Organisational Studies

Boisot, M. (1998) Information Space, London: Routledge

Boreham, N (1999)

Brennan, J. et al (2001)The employment of UK graduates: comparisons with Europe and Japan HefCE. Bristol

Brown, J. S. and Duguid, P. (1991) Organisational Learning and Communities of Practice: Towards a Unified View of Working, Learning and Innovating Organisational Science 2.1.

Brown, J. S. and Duguid, P. (2001) Knowledge and Organisation: a social-practice perspective Organizational Science Vol, 12, No. 2. pp 198-213

Brown, J. S. Duguid, P. (2000) The Social Life of Information, Harvard Business Press, Harvard, 
Canny, A. and Hughes, G. (1995), Occupational Forecasts for 1998 for Ireland and their implications for educational qualifications. Paper for meeting of CEDEFOP network 'CIRETOQ' Marseilles 20-21, November

Castells, M. (1996) The Rise of the Network Society, Vol 1. MacMillan, London

CEDEFOP (1998) Vocational Education and Training - the European Research Field, Vol 1, CEDEFOP, Thessaloniki

Chisholm, L. (1999) From Systems to Networks: the Restructuring of Youth Transitions, in Heinz, W.R. (ed) From Education to Work: Cross national perspective, CUP. Cambridge, UK

Coffe, D. (1996) Competing in the Age of Digital Convergence Jossey Bass San Franscisco

Cooke. P. and Morgan, K. (1998) The Associational Economy,

Crouch, C. Finegold, D. Sako, M. (1999) The Political Economy of Skill Creation in Advanced Industrial Societies, Oxford: Oxford University Press

Darrah, C (1994) Skill requirements At Work in Work and Occupations, Vol 21. No 1. 64-84

Dreyfuss H, L. and Dreyfuss S, E. (1986) Mind Over Machine. Oxford: Blackwell.

Drucker, P. (1993) The Post-Industrial Society Heinemann, London

EC (1997) Learning in the Information Society: Action Plan for a European Initiative, Brussels: EC

EC (1995) Teaching and Learning: Towards the Learning Society, Brussels: EC

Engeström, Y (1996a) 'Development as breaking away and opening up: A challenge to Vygotsky and Piaget', Swiss Journal of Psychology, 55 126-132

Engeström, Y. and Gronin, T. (forthcoming) Transfer and Boundary Crossing.

Engeström, Y., Engeström, R., and Karkkainen, M. (1995 (a)) 'Polycontextuality and boundary crossing in expert cognition: Learning and problem solving in complex work activities' Learning and Instruction 5. 1. pp. 319-366

Engeström, Y. (1995 (b)) Training for Change, International Labour Office: London

Eraut, M. (1999) Learning in the workplace - a framework for analysis. Paper presented at the EARLI Conference on Working and Learning.

Finegold, D (1999). 'Creating Self-Sustaining, High-Skill Ecosystems', Oxford Review of Economic Policy, Vol 15. No 1. 60-81 
Fischer, M. and Stuber, F. (1998) 'Work process knowledge and school-to-work transition' in Scherer, E., ed. Shop Floor Control: A Systems Perspective Berlin: Springer Verlag

Flecker, J and Hofbauer, J (1998) Capitalising on Subjectivity: The New 'Model Worker' and the Importance of Being Useful, in Warhurst, P. and Thompson, C. Workplaces of the Future, London, MacMillan

Florida. R. (1995) 'Toward the Learning Region', Futures, Vol 27. No 5. 527-536

Freeman, C. (1997) Technical Change and Unemployment in Philpott, K. (ed) Working for full employment, London, Routledge

Green, A., Lauder, H., Brown, P. and Sakamoto, A. (forthcoming) High Skill Economies

Green, A., Leney, T. and Wolf (1999) Convergence and Divergence in European Education and Training Systems, London: Bedford Way Papers, Institute of Education, University of London.

Green, A., Leney, T. and Wolf (1999) Convergence and Divergence in European Education and Training Systems, London: Bedford Way Papers, Institute of Education, University of London

Green, F. (1999) The Market Value of Generic Skills Skills Task Force Research Paper 17. DfEE, Suffolk

Griffiths, T., Benke, M., Guile, D., Herlau, H., Madsen T., Marhuenda, F., McKenna, P. (2001) Work experience as a strategy for learning in Europe EU. Brussels

Griffiths, T. and Guile, D. (1999) 'Pedagogy in work-based contexts', in Mortimore, P., ed., Understanding pedagogy and its impact on learning, London: Sage Publications

Guile, D. Griffiths, T. (forthcoming) Work, Knowledge and Learing: issues for research, policy and practice CEDEFOP: Tessaloniki

Guile, D. Young, M. (forthcoming) Transfer and transition in vocational education: some theoretical considerations in Engeström, Y. and Gronin, T. (forthcoming) Transfer and Boundary Crossing

Guile, D. and Griffiths, T. (2001) 'Learning through work experience', Journal of Education and Work

Guile, D. and Fonda, N. (1999) Managing Learning for Added Value London: Institute of Personnel and Development

Hamel, G. Prahalad, C.K. (1994) Core Competencies

International Labour Office (1999) World Employment Report (1998) 1989-99 Employability in the Global Economy. How Training Matters, ILO, Geneva 
Jessup, G. (1990) Outcomes: NVQs and the emerging model of education and training Brighton: Falmer Press

Kämäräinen, P., Attwell, G. and Brown, A. (forthcoming) eds, Qualifications, Competences and Learning Environments for the Future: European Reference Publication, Thessaloniki: CEDEFOP

Kämäräinen, P. and Streumer, J. (1998) 'Curriculum Development, New learning environments, and transfer of innovations in Europe' in CEDEFOP Vocational Education and Training - the European research field. Background Report 1998 Vol II CEDEFOP, Thessaloniki, Greece

Keep, E. and Mayhew,K. (1999) 'The Assessment: Knowledge, Skills and Competitiveness', Oxford Review of Economic Policy, Vol 15. No 1. 1-16

Keep, E. (1999) UK's VET Policy and the 'Third way': following a high skills trajectory or running up a dead end street? Journal of Education and Work, Vol 12, No 3. 323-346

Kim, W. and Mauborgne, R. (1999) Strategy, Value Innovation, and the Knowledge Economy, Sloan Management Review 41-54

Kruse, R. (1996) Work process knowledge and quality of vocational training, paper given at the Third Work Process Knowledge Meeting, Bremen, Dec 12-14

Lave, J. and Wenger, E. (1991) Situated Learning, Cambridge: Cambridge Press

Lundvall, B.A. (ed) (1992)National Systems of Innovation Pinter Publishers, London

Machlup. F. (1962) The Production and Distribution of Knowledge in the United States NJ: Princeton University Press

Nickel \& Bell (1995)

Nickson, D., Warhurst, C., Witz, and Cullen A.M. (1998) Aesthetic labour in the Service Economy, paper presented to the 3rd Labour Market Conference, Aberdeen

Nonaka, I and Teece, D. (2001) Managing Industrial Knowledge Sage, London

Nonaka, I and Takeuchi, H. (1995) The Knowledge Creating Company OUP, New York, USA

Oesterman, P. (1994) How Common is Workplace Transformation and Who Adopts It? Industrial and labour Relations, Vol 47. No 2. 173188

Onstenk, J. (forthcoming) Transfer, occupational core problems and the vocational curriculum in Engestrom, Y. and Tuomi-Gronin, T. (ed) Transfer and Boundary Crossing, Elsevier, Amsterdam

Oliver et al (1999) 
Organisation for Economic Co-Operation and Development (1997) Changing Workplace Strategies: Achieving Better Outcomes for Enterprises, Workers and Society, OECD, Paris

Organisation for Economic Co-operation and Development (1996) High Performance Workplaces, OECD, Paris.

Organisation for Economic Co-Operation and Development (1996) The OECD Jobs Strategy, technology, productivity and job creation, OECD, Paris

Organisation for Economic Co-Operation and Development (1996) The KnowledgeLearning Economy: from the Economics of Knowledge to the Learning Economy, OECD, Paris.

Ostenk, J. (1998)

Payne, J. 'All Things to All People: Changing perceptions of 'Skill' Among Britain's Policy makers Since The 1950s and their Implications, SKOPE Research Paper No 1. SKOPE, Warwick Business School, Warwick University, Coventry, UK

Prahalad, C.K. and Ramaswamy, V. (2000) Co-Opting Customer Competence, Harvard Business Review, Jan-Feb, 79-87

Regini, M. (1995) 'Firms and institutions: the demand for skills and their social production in Europe', European Journal of Industrial Relations, 1. 2. pp: 191-202

Stern, D. and Wagner, D. A., ed. (1999) International Perspectives on School-to-Work Transition Cresskill N. J., USA: Hampton Press

Reich, R. (1991) The Work of Nations, Basic Books, New York

Research Centre for Education and the Labour Market (ROA) (1995), The labour market by education and occupation to 2000, Maastricht

Robinson (1997)

Schumann, M. (1998). New Concepts of Production and Productivity. Economic and Industrial Democracy, 19, 1, 17-32

Simelot

Spender, J.C. Grant, R. Knowledge and the Firm: Overview Strategic Management Journal Vol 17. No 1. Winter Special, Issue 5-9

Stehr, N (1994) Knowledge Societies Routledge, London

Szulanski, G (1996) Exploring internal stickiness: impediemtns to the trnsfer of best practices in the firm Strategic Management Journal 17 (Winter Special) 27-43 
Taylor, A. (1998) Employability Skills: From corporate wish list to government policy in Journal of Curriculum Studies, 30.2. 143-164

Tessaring, M. ( 1997) The relationships between education, training, employment and the labour market - some research findings and conclusions, CEDEFOP Panorama, Seminar Papers, Luxembourg

Thurow, L. ( 1999) Creating Wealth Nicholas Brearley London

Victor and Boynton (1998),

Von Krogh, G. and Cusumano, M.A. (2001) Three Strategies for Fast Growth Sloan Management Review Vol 9 Winter pp 53-64

Watkins, J. (1998) Information technology, organisations and people: Transformations in the UK retail and financial services sector London, Routledge

Wilson, R.A.and Webb, T.J. (1995) Review of the economy and employment, Occupational Assessment, Institute of Employment Research, Warwick University, UK.

Womack, J.P. Jones,D. and Roos, D. (1990) The Machine that Changed the World. New York, Rawson, International Journal of Lifelong Learning Vol 18. No 5. pp 395405

Young, M.F.D. (2000) 'Bringing knowledge back in: towards a curriculum for lifelong learning' in Hodgson, A. (ed) Policies, Politics and the Future of Lifelong Learning, London: Kogan Page

Young, M.F.D. (1998) The Curriculum of the Future, London, Falmer Press

Young, M. (1999) Improving Vocational Education: Trans-European comparisons of development in the late 1990s, Paper presented to SPESNET Workshop, Flensburg Germany Oct 6-10,

Zubboff, S. (1988) In the Age of the Smart Machine. London: Heinemann. 


\section{Table 1}

\section{A typology of generic skill.}

\begin{tabular}{|c|c|c|c|}
\hline & & Nature of & Work Activities \\
\hline $\begin{array}{l}\mathbf{C} \\
\mathbf{o} \\
\mathbf{n} \\
\mathbf{c}\end{array}$ & FOCUS & $\begin{array}{l}\text { Routine } \\
\text { problems }\end{array}$ & $\begin{array}{c}\text { Novel } \\
\text { problems }\end{array}$ \\
\hline $\begin{array}{l}\mathbf{e} \\
\mathbf{p} \\
\mathbf{t} \\
\mathbf{i} \\
\mathbf{o} \\
\mathbf{n} \\
\mathbf{s}\end{array}$ & $\begin{array}{l}\text { Individual conception of } \\
\text { skill }\end{array}$ & $\begin{array}{l}\text { Key Skills (i.e. certified } \\
\text { evidence of literacy, } \\
\text { numeracy and IT) }\end{array}$ & $\begin{array}{l}\text { Intrapreneurial } \\
\text { skills (i.e. ability to work } \\
\text { effectively in immediate } \\
\text { work context) } \\
\text { Symbolic analytical skills } \\
\text { (i.e. ability to apply } \\
\text { specific form of } \\
\text { expertise) }\end{array}$ \\
\hline $\begin{array}{l}\mathbf{S} \\
\mathbf{k} \\
\mathbf{i} \\
\mathbf{l} \\
\mathbf{l}\end{array}$ & $\begin{array}{l}\text { Contextual conception } \\
\text { of skill }\end{array}$ & $\begin{array}{l}\text { Key qualification } \\
\text { (i.e. using technical, } \\
\text { socio-cultural and } \\
\text { participative competence } \\
\text { in the workplace) }\end{array}$ & $\begin{array}{l}\text { Polycontextual skills (i.e. } \\
\text { ability to mediate } \\
\text { between different forms } \\
\text { of expertise) } \\
\text { Intellective skills (i.e. } \\
\text { ability to mediate } \\
\text { between symbolic data) } \\
\text { Boundary crossing skills } \\
\text { (i.e. ability to operate } \\
\text { effectively in different } \\
\text { contexts) }\end{array}$ \\
\hline
\end{tabular}

